\title{
PI3K-C2 $\alpha$ regulates Polycystin-2 ciliary entry to prevent kidney cyst formation
}

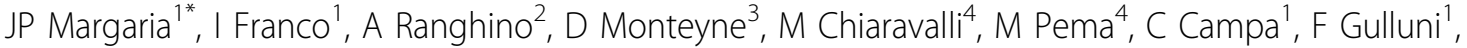 \\ D Perez-Morga ${ }^{3,4,5}$, G Merlo $^{1}$, A Boletta ${ }^{4}$, E Hirsch ${ }^{1}$ \\ From Cilia 2014 - Second International Conference \\ Paris, France. 18-21 November 2014
}

\section{Objective}

PI3K-C2 $\alpha$ is a regulator of vesicle recycling at the base of the primary cilium and is required for the targeting of ciliary components. Here we sought to understand whether PI3K-C2 $\alpha$ is required for the targeting of Polycystin-2 to primary cilia and the consequent regulation of kidney cyst formation.

\section{Methods}

Homozygous mutation of $P i k 3 c 2 a$, the gene encoding for PI3K-C2 $\alpha$, is embryonic lethal. Hence, the function of PI3K-C2 $\alpha$ in kidney cilia has been studied both in vitro, in Pik3c2a-silenced IMCD3 cells, and in vivo, in Pik3c2aheterozygous mice, using an Ischemia/Reperfusion model of renal injury.

\section{Results}

$\mathrm{PI} 3 \mathrm{~K}-\mathrm{C} 2 \alpha$ resides at the recycling endosome compartment surrounding the primary cilium base where it controls the activation of Rab8, a key mediator of cargo protein targeting to the primary cilium. Consistently, partial reduction of PI3K-C2 $\alpha$ is sufficient to impair elongation of the cilium both in Pik3c2a-silenced IMCD3 cells and in kidney tubules of Pik3c2a $a^{+/-}$mice. Importantly, absence of PI3K-C2 $\alpha$ impairs the Rab8-dependent transport of Polycystin-2 to cilia and produces an overactivation of proliferative pathways regulated by ciliary Polycystins, such as the mTOR and MAPK pathways. Both defects can be rescued by transfection of constitutively active Rab8. In line with defective Polycystin signaling, heterozygous deletion of PI3K-C2 $\alpha$ in mice causes an overall deregulation of proliferative signals in response to Ischemia/Reperfusion-

'Department of Molecular Biotechnology and Health Science, University of Turin, Turin, Italy

Full list of author information is available at the end of the article induced renal damage, and this condition predisposes to cyst development.

\section{Conclusion}

These results indicate that $\mathrm{PI} 3 \mathrm{~K}-\mathrm{C} 2 \alpha$ is required for the transport of ciliary components like Polycystin-2 and that reduction in PI3K-C2 $\alpha$ levels is sufficient to enhance susceptibility to cystic kidney disease.

\section{Authors' details}

${ }^{1}$ Department of Molecular Biotechnology and Health Science, University of Turin, Turin, Italy. ${ }^{2}$ Department of Medical Sciences, Dialysis and Transplantation, Renal Transplantation Center "A. Vercellone", Turin, Italy. ${ }^{3}$ Institut de Biologie et de Médecine Moléculaires (IBMM), Laboratoire de Parasitologie Moléculaire, Université Libre de Bruxelles, Charleroi, Belgium. ${ }^{4}$ Division of Genetics and Cell Biology, Dibit San Raffaele Scientific Institute, Milan, Italy. ${ }^{5}$ Center for Microscopy and Molecular Imaging-CMMI, Charleroi, Belgium

Published: 13 July 2015

\section{doi:10.1186/2046-2530-4-S1-O}

Cite this article as: Margaria et al:: PI3K-C2 $\alpha$ regulates Polycystin-2 ciliary entry to prevent kidney cyst formation. Cilia 2015 4(Suppl 1):01.

Submit your next manuscript to BioMed Central and take full advantage of:

- Convenient online submission

- Thorough peer review

- No space constraints or color figure charges

- Immediate publication on acceptance

- Inclusion in PubMed, CAS, Scopus and Google Scholar

- Research which is freely available for redistribution 